\title{
Our Job in Japan
}

\section{Making Sense of the American Creed}

\author{
Jeffrey M. Hornstein
}

There were essentially two types of film propaganda produced in the United States during the Second World War. The first, and most widely acknowledged by historians, was the variety created by Hollywood studios at the behest of, or in collaboration with, the Office of War Information and its Bureau of Motion Pictures. The Why We Fight series by Frank Capra is undoubtedly the best known example of Hollywood-government collaboration. The second type includes those films made by the government itself, either for export as part of 'public information' campaigns, or for training troops for particular missions. This latter category has generally been ignored by historians. This paper will analyze one such film, Our Job in Japan, which was produced as an orientation film for the American occupation forces sent to Japan at the end of the Second World War. ${ }^{1}$ As a cultural text, this film demonstrates that

1 Our Job in Japan, Motion Picture 111 OF 15 (Orientation Film No. 15), Records of the Office of the Chief Signal Officer, Record Group 111, National Archives, Washington, DC. The film project was supervised by Theodore "Dr. Seuss" Geisel, and the script was written by Geisel and Carl Foreman. 
this under-explored genre of propaganda is a revealing source of material for exploring official attempts to construct and communicate an idealized vision of American society and to create sharp distinctions between the ideal American Self and foreign Others. ${ }^{2}$ In the manner of cultural studies, I will read the film through the eyes of Swedish social scientist Gunnar Myrdal, whose 1944 classic An American Dilemma: The Negro Problem and Modern Democracy identified many of the same cultural tensions which are latent in the film Our Job in Japan.

Myrdal's text appeared just as Our Job in Japan was being conceived, and both are symptomatic of the ways in which racism came to be identified as a public problem, an issue which would dominate postwar social policy discussions. The film's ostensible purpose is to orientate American troops for their task in occupying Japan - the territory of another 'race' - but the subtext of the film is the American dilemma. As the behind-the-screen discourse contained in the production files demonstrates, the culture producers within the American military were aware of what Myrdal called the 'is-ought' gap in American society, and their films, of which Our Job in Japan is but one example, may be seen as part of an attempt to obscure the rift through film. As my analysis will demonstrate, societal anxiety not to see the Self in the Other was not fully erased, and the socio-cultural reality of 1940 s America manifests itself in the film despite the editor's efforts at concealment.

2 As an employee in the Motion Picture, Sound, and Video Research room of the National Archives in College Park, MD, it is my impression that but a few cultural historians have begun to tap into the rich collection held by the Archives of such films, particularly in RG 111 OF and RG 306 (United States Information Agency). See John Morton Blum, $V$ Was For Victory: Politics and American Culture During World War II (New York 1976), and Richard Polenberg, One Nation Divisible: Class, Race, and Ethnicity in the United States Since 1938 (New York 1980) for excellent cultural histories of wartime America which make good use of the Hollywood genre of propaganda films as sources. 


\section{The American Creed and its Dilemma}

To Gunnar Myrdal, invited by the Carnegie Corporation in 1940 to study the "Negro Problem" from an 'outsider's' perspective, the United States was distinguished from the rest of the world, and particularly from Europe, by its "moralism and rationalism," which he saw as "the glory of the nation, its youthful strength, perhaps the salvation of mankind." The massive (1500 page) tome produced by Myrdal and his team of researchers aimed "to ascertain social reality as it is ... to depict the actual life conditions of the American Negro people and their manifold relations to the larger American society." The researchers started from the premise that "material facts in large measure are the product of what people think, feel, and believe." From this perspective, Myrdal suggests, "the actual conditions ... indicate the great disparities between the whites' and the Negroes' aspirations and realizations.",3

The "Negro Problem," as Myrdal saw it, was a "moral issue of conflicting valuations." The essence of the issue was a "moral dilemma of the American - the conflict between his moral valuations on various levels of consciousness and generality." The "American Dilemma," the author asserts,

is the ever-raging conflict between, on the one hand, the valuations preserved on the general plane, ... the 'American Creed,' where the American thinks, talks, and acts under the influence of high national and Christian precepts, and, on the other hand, the valuations on specific planes of individual and group living, where personal and local interests; economic, social, and sexual jealousies; considerations of community prestige and conformity; group prejudice against particular persons or types of people; and all sorts of miscellaneous wants, impulses, and habits dominate his outlook.

3 Gunnar Myrdal, An American Dilemma: The Negro Problem and Modern Democracy (New York 1944), xlvi, xlix. 
Thus the "dilemma" is a complex tension between the personal and the social, between local and the national values, tensions which mirrored the project of the New Deal in general. In fact, the ostensible starting point for Myrdal's curiosity about American society is the ability of Americans to "fiercely be prejudiced against Negroes, while at the same time subscribe wholeheartedly to the American Creed." Actual behavior, the author posits, is "the outcome of a compromise between valuations."4

Anticipating what would later be termed the "consensus school" of American historiography, Myrdal asserts the "cultural unity" of the American "nation," which suggests "that most Americans have most valuations in common though they are arranged differently in the sphere of valuations of different individuals and groups and bear different intensity coefficients." $\mathrm{He}$ called these larger unifying ideals the "American Creed," and he foreshadowed Louis Hartz's Liberal Tradition in America in arguing that "America, compared to every other country in Western Civilization, has the most explicitly expressed system of general ideals in reference to human interrelations." This Creed comprised the "ideals of the essential dignity of the individual human being, of the fundamental equality of all men, and of certain inalienable rights to freedom, justice, and a fair opportunity." Of course, Myrdal notes, "the Creed of America is not very satisfactorily effectuated in actual social life. But as principles which ought to rule, the Creed has been made conscious to everyone in American society." In other words, this conscious national Creed is sub/unconsciously abrogated on the local/personal level. Most interesting

4 Myrdal, American Dilemma, xvii, xlviii. The local-national tension inherent in the New Deal is depicted in such cultural products as John Ford's 1940 production of John Steinbeck's The Grapes of Wrath, in which the only benevolent and just authority figures are those of the federal government, while local officials are portrayed as lawless yahoos.

5 Myrdal, American Dilemma, xlviii. Like the consensus school, Myrdal's research was heavily influenced by the emerging dominant paradigm in American social science, structural-functionalism. 
to Myrdal is that "with one part of themselves [Negroes] actually believe, as do the whites, that the Creed is ruling America."6

Liberalism had achieved ideological hegemony in American society, Myrdal argues, because "principles of social ethics" had been "hammered" into simple formulas. A vast array of "intellectual communication" are utilized to "stamp" them into the public mind. The schools and the churches propagate the formulas, the courts base judicial decisions upon them. These principles, Myrdal asserts, "permeate editorials with a pattern of idealism so ingrained that writers could scarcely free themselves from it even if they tried." He wonders at the fact that a culturally-diverse democratic society was "able to realize this unanimity of ideals and to elevate them supremely over the threshold of popular perception," an achievement unmatched by totalitarian fascism. ${ }^{7}$ These "principles of social ethics," as well as their internal contradictions, also permeated American wartime propaganda.

\section{Democracy, War and Propaganda}

For many American historians, the Second World War represented a more interesting and insidious experiment in social control than did the previous world war because the medium of film was much more highly developed, and the film industry was quite willing to collaborate with the government to produce high-quality propaganda. ${ }^{8}$ As early as the late 1930 s, military officials such as General George Marshall had appreciated the power of film, particularly its ability to affect morale. As David Culbert argues, the liberals who

6 Myrdal, American Dilemma, 4.

7 Myrdal, American Dilemma, 4, 6.

8 Allied efforts at persuasion were rarely if ever publicly referred to as "propaganda," but were assigned euphemisms such as "public information" or "education." As former WWII propagandist Eric Barnouw has written, "propaganda was what others did, especially the Germans." See K.R.M. Short, ed., Film and Radio Propaganda in World War II (London 1983), preface, 1 . 
ran the government's propaganda apparatus during the Second World War were motivated by a "Social Engineering" ideology, which he defines as "the need to offer a reason why to an educated citizenry ... Acceptance of state policy ... demanded some reason why. Not necessarily the whole truth, but at least plausible justification." 9 The American propaganda effort, over which the Office of War Information (OWI) became the central coordinating body, "told the truth by degrees and with a particular bias ... [OWI was] an organization designed not only to disseminate information and to clarify issues but also to arouse support for particular ideas and symbols." In the words of OWI chief Elmer Davis, "the easiest way to inject a propaganda idea into most people's minds ... is to let it go in through the medium of an entertainment picture when they do not realize they are being propagandized.",10

The OWI, as Koppes and Black put it, "demanded affirmation of New Deal liberalism for America and the world." Thus, it is not surprising to read the manual for the motion picture industry produced by OWI's Bureau of Motion Pictures (BMP), which informs the film industry that the war is not "a national, class, or race war," but is instead to be seen as a "people's war." The enemy was fascism itself, and the manual instructs that "any form of racial discrimination or religious intolerance, special privileges of any citizen are manifestations of Fascism and should be exposed as such." The BMP, whose main lever was control over film export licenses - and hence, indirectly over the production of large budget pictures - would not tolerate films which dealt with segregation, or which dealt critically with the internment of Japanese-Americans. The BMP's revised code promulgated in December 1942 banned export films that showed rationing or other

9 David Culbert, "WWy We Fight': Social Engineering for a Democratic Society at War," in Short, Film and Radio Propaganda in World War II, 174-5.

10 Davis cited in Clayton Koppes and Gregory Black, "What to Show the World: The Office of War Information and Hollywood, 1942-1945," Journal of American History (June 1977), 88. 
economic preparations for a long war, scenes with lawlessness in which order was not restored and the offenders punished, and portrayals of labor or class conflict in the US since 1917. The BMP's position was not that films should deny that the United States had problems, but that they should emphasize the ways in which democracy solved them. For example, the film initially entitled Where Are Your Children?, which depicted juvenile delinquency, teen pregnancy, and suicide, was ordered amended by the OWI because the film did not provide a proper solution to the problems. The film was ultimately released as Look to Your Children, with a conclusion, according to a reviewer, comprised of "stock shots showing how the Boy Scouts, 4-H Clubs, city playgrounds, and similar institutions are combating juvenile problems." In the words of Koppes and Black, "like sin punished in the end, democracy solving its problems was ruled suitable for export." On the other hand, such films dealing with the Soviet Union as Mission to Moscow, were criticized by reviewers for being too forgiving of Stalinism, the purges, and the Soviet occupation of Finland. $^{11}$

\section{Our Job in Japan and and its Historical Imagination}

Our Job in Japan was produced as an orientation film for the American occupation forces sent to Japan at the end of the Second World War. The film, officially Project \#11,013 and initially entitled "Your Job In Japan," began production in the immediate aftermath of the atomic bombing of Japan, and was probably conceived prior to it. The earliest document in the film's production file, a memorandum from the director of the Information and Education Division regarding revisions in the I \& E Division film budget, is dated 28 August 1945 and indicates that "Your Job In

11 Koppes and Black, "What to Show the World," 90- 1, 100-2. 
Japan" was a high priority project: while many other I \& E film projects were slated for cancellation, the production unit for "Your Job in Japan" was "to be maintained on the West Coast as long as needed." 12 The title was changed to "Our Job In Japan" for reasons which go unmentioned in the extant production files, and the credit title cards were changed to read "Information and Education Division, War Department," to reflect the incorporation of the I \& E Division into the War Department's General Staff. ${ }^{13}$

As a cultural text, the film is very revealing both in its depiction of the Japanese Other, and of the American Self, and is a powerful example of the tension between representation and reality, between the American Creed and American reality identified contemporaneously by Myrdal in An American Dilemma. Military orientation films such as Our Job in Japan are particularly interesting cultural documents precisely because they were produced by the government for rank-and-file soldiers and not in collaboration with Hollywood as general-distribution propaganda pieces, and thus they represent in nearly pure form the official American position. Moreover, the production files make it clear that military officials were very cognizant of making the correct impact on the presumably impressionable GIs. As the behind-the-screen discourse demonstrates, the culture producers within the American military were aware of the "is-ought" gap in American society, and their films, of which Our Job in Japan is but one example, may be seen as part of an attempt to erase the rift through film.

Among the tensions running through Our Job in Japan is that between authoritarianism and paternalism, particularly toward one of the main protagonists in the film, the "Japanese Brain." In many respects this tension epitomizes the problematic postwar American

12 Colonel W.B. Hayes, Fiscal Officer, Information and Education Division, to Chief, Army Pictorial Service, 28 August 1945; Motion Picture Production File, 111 OF 15; Record Group 111; National Archives, Washington, DC; hereafter cited as MPPF 111 OF 15.

13 Captain Lehman Katz, Chief, M.P. Production Branch, to Commanding Officer, Signal Corps Photographic Center, 2 November 1945; MPPF 111 OF 15 . 
self-image. Caught between containment and building a supposedly liberal new world order, the postwar Americanism implicit in this film is composed of two strands, one xenophobic, and the other self-confident bordering on arrogant. Additionally, much irony exists in the film's explicit presentation of the American Creed as nondiscriminatory, particularly in light of the conditions of statutory segregation which prevailed throughout at least half of the United States in 1945, and in the military itself. Harry Truman's desegregation order was three years in the future, and the mass social movements which culminated in Civil Rights legislation were still further away. In short, the film is an example of what Michael Schudson has aptly termed "capitalist realism" - America and its Creed as elites imagine it. ${ }^{14}$

The film begins with a massive display of American military hardware, and segues into MacArthur's speech aboard the USS Missouri as the surrender agreements are signed by Japanese officials. The first voice heard by the viewer is that of the soon-tobe Supreme Ruler of Japan, Douglas MacArthur:

It is my earnest hope, and indeed the hope of all mankind, that from this solemn occasion a better world shall emerge out of the blood and carnage of the past. ${ }^{15}$

The film, as well as the Occupation itself, has two primary themes, Demilitarization and Democratization. The first task of the film is to explain to the soldiers the genesis of "fanatical" Japanese wartime militancy; the root of the problem, they are told, is located in the malleable Japanese Brain. The second purpose is to state the American mission in Japan, which is to guide this Japanese Brain toward understanding The Truth - i.e., the superiority of "The American Way, or democracy, or just plain old golden-rule common sense," which the prewar Brain obviously lacked - in

14 Michael Schudson, Advertising: The Uneasy Persuasion (New York 1985).

15 Author's transcription, Our Job in Japan. This scene was not included in the script. 
expectation that it will choose a form of government that will prevent future wars (and one which would be responsive to American policy goals).

The content of this Truth as articulated in the film - and its contradictions with reality - is essentially identical to what Myrdal called the American Creed. The political system transplanted to postwar Japan was, in historian Herbert Passin's words, "a generalized or transmogrified American model" which changed, among other things, the prewar French-style prefecture system into an American style of federalism. In a sense, then, the Occupation allowed twentieth-century Americans to attempt to recreate the founding experience under more or less authoritarian conditions. ${ }^{16}$

There are three corporate actors in the film. First, the evil, insatiably imperialistic "Warlords" and their puppets in the Shinto clerical hierarchy; second, the innocent and malleable "Japanese Brain," of which there are "seventy million" (yet, treated in the film as if one); and third, the benevolent yet stern American "Fathers" of the Occupation force. The basic plot is that the imperially ambitious Warlords, via treachery and clever exploitation of the ancient strands of Japanese consciousness, whipped the Japanese masses into fanatical support for their efforts, leading to the inevitably suicidal and "repulsive" war, which, the film emphasizes, "turned the stomach of the entire Civilized World." Despite the animosities engendered by the war, the noble American Father arrives to protect the Brain from a return of the Warlords, so that it might peacefully learn The Truth and make the great leap forward into modernity, thereby becoming invulnerable to this sort of

16 Herbert Passin, "The Occupation - Some Reflections," Daedalus (Summer 1990), 114. In contrast to the postwar occupation of Germany, the occupation of Japan was conducted via indirect rule. In practice, this meant that "directives were issued to the Japanese government."(Ibid 109) For an interesting discussion of the implications of and motivations behind the occupation, see Justin Williams, Sr., "American Democratization Policy in Occupied Japan: Correcting the Revisionist Version," Pacific Historical Review (Fall 1988), 179-202, and rejoinders in the same issue by John Dower and Howard Schonberger. 
"brainwashing" in the future. Just to be sure, the good Father destroys the means of military production.

The film's producers assumed a lack of knowledge of Japanese history and culture in the rank-and-file, as well as biases against the Japanese people strengthened by intense wartime propaganda and combat experience. In this context, the strategy of the film is clever: two different narrators are employed, one with a clearly authoritarian voice and the other with a paternalistic tone. The film itself is divided somewhat abruptly and unevenly into two acts and a coda, corresponding to the themes of the Occupation. The first and lengthiest section, related by the authoritarian narrator, presents the key problem facing American occupation troops: the Japanese Brain has been perverted by backwardness and fanaticism, and needs to be (re)filled with "modern, sensible" ideas. This section of the film depicts the central role of the Shinto religion as a fascist tool, used to "hammer the idea" that the Japanese people were "created to rule the whole world," a phrase which is repeated half a dozen times throughout the fifteen-minute film, both verbally and in bold, screen-dominating type. The second section, paternalistic in tone, depicts the crucial part to be played by the American occupiers as role models for their Japanese "children" who have been led astray by the power-hungry Warlords and their clerical lackeys. The coda reverts to the authoritarian theme, reminding the GIs (and the Japanese) that the US will occupy Japan until it is "under control," that is, until the Japanese Brain has been properly reprogrammed for "modern" life.

\section{Depicting the Other}

The image of the Japanese Brain recurs throughout the film, and is used most often to symbolize the susceptibility of the "premodern" Japanese people to "mumbo jumbo," "hokum," "old ideas," and "superstition," all characteristic of Japanese culture before the war. The Brain first appears superimposed upon the head of what is ostensibly an office worker, and three times expands to fill the 
entire screen. It is depicted as a vessel, which may be filled with either "evil, ancient, and superstitious" or "good, modern, and sensible" ideas. Naturally, since the former ideas "lost" the war, the ideas of the victors must be superior. ${ }^{17}$

Our problem's in the brain inside the Japanese head. There are seventy million of these in Japan. [Image of a human brain fills the screen.] Physically, no different than any other brains in the world. Actually all made of exactly the same stuff as ours. These brains, like our brains, can do good things ... or bad things, all depending on the kind of $i d e a s$ that are put inside. None of them was ever born with a dangerous idea ... Any sensible idea ... Any modern idea ... the Japanese brain, like our brain, can learn when it is taught. And it was beginning to learn these things in an old, backward, superstitious country. ${ }^{18}$

The Japanese Brain, the authoritarian narrator asserts, was corrupted out of its budding modernist sensibilities by the evil Warlords who "had their own plans." They were able to succeed in seducing the masses to "play follow the leader" because the Brain was only partly modernized. The Warlords coopted the "dying" Shinto religion for their imperialistic purposes:

With such a brain ... with its mixture of ancient and modern, some very interesting things could be done. A brain that thought in the modern way could be taught to use the latest modern weapons. A brain that also thought in the ancient way could be hopped up to fight with fanatical fury. If [the Warlords] could hop it up, then the sky would be the limit to the things that they could do. They'd gain

17 Twentieth century American elites are remarkably consistent in emphasizing the superiority of "American ideas" in response to the failure of other systems, as if the ideas themselves "won" a battle, or that the fall of the Other proves the preeminence of the Self. This tendency, which to this author demonstrates a severe national inferiority complex, was first articulated by Daniel Bell in his The End of Ideology: On the Exhaustion of Political Ideas in the Fifties (Glencoe, Ill. 1960). It was been carried to new and absurd extremes in the late 1980s and early 1990s; see Frances Fukuyama, "Have We Reached the End of History?" The National Interest (1989).

18 Narration Script - Project \#1 1013, OUR JOB IN JAPAN, 13 September 1945; MPPF OF 15, 4-5. 
power, glory, and a great new worldwide empire that they could control as their own ... IF they were smart enough to do tricks with the Japanese brain. They were smart enough. ${ }^{19}$

The "mumbo jumbo" and "hokum" of the Shinto religion, so the story goes, were used cleverly by the Warlords as an indoctrination tool. The Warlords used Shinto to revive ancient ideas, and, combined with features of modernity, such as high-tech weapons, the worst of both the past and present were fused into a fierce and ruthless fighting machine. Building up to the climax of this section, extended scenes of hypnotic ritual dances and chants, plainly intended to accentuate the "irrationally exotic" and non-Western nature of the ancient religion, are overlain with the narrator's rising voice:

Tell them that the soldiers of yesterday are the Japanese gods of today. Tell them that a Japanese warrior never dies. Play up the myth of the goddess of the sun. And over and over and over again, keep on telling them and telling them and telling them just this: "The Sun Goddess created the Japanese to rule all the other people of the earth." ${ }^{20}$

The phrase, "CREATED TO RULE THE WHOLE WORLD," recurs throughout the film to reemphasize the intensity of programming the Brain had undergone, and the "patience" the deprogramming process will require. The Warlords and their Shinto priest accomplices were able to force the Japanese Brain and body to "bow and say it" so often they began to believe it:

Fanatically convinced that the Japanese family was especially created for one single purpose ... to crush and to conquer and to rule like gods over all the other people of the earth. ["CREATED TO RULE THE WHOLE WORLD" fills the screen.] And they tried to ...all because of one idea that was sold to the Japanese brain. That same brain today remains the problem. Our problem. ${ }^{21}$

19 Narration Script - Project \#11013, 5-6.

20 Narration Script - Project \#1 1013, 8.

21 Narration Script - Project \#11013, 10. 
As with a delinquent child, the Occupationeers (to borrow Herbert Passin's felicitous term) had to be both stern and benevolent with the Japanese people, on the one hand dealing harshly with "troublemakers," and on the other, ensuring freedom and leading by example:

Our job is to see that they [think their way out of this stuff]. Our job is to watch them while they do it. To watch them for tricks. To slap down any that try to pull tricks. [Images of GIs frisking Japanese soldiers.] But the honest ones, the sincere ones, the ones who really want to make sense, are being given every opportunity they need. ${ }^{22}$

The "conquering army," however, is willing to "take no more chances" in driving home the point that "THIS IS JAPAN'S LAST WAR" - which appears in bold type superimposed upon the Brain as the first act reaches its (second) climax:

And we are starting to prove that point by completely destroying their power to make war. There'll be no more Japanese war factories [BOOM]. There will be no more Japanese war lords $[\mathrm{BOOM}]$. No more Japanese war ships [BOOM]. No more Japanese war planes $[\mathrm{BOOM}]{ }^{23}$

However, the authoritarian narrator notes, "that is the easiest part" of the job - "it'll take a lot longer to get rid of their idea" ['CREATED TO RULE THE WHOLE WORLD' fills the screen once again]. The mission of the Occupation forces, stresses the authoritarian narrator, is to "watch them" while they erase from the Brain the falsities of the Imperial ideology, and inscribe the truth on the resulting tabula rasa:

Now if they want to read the truth, the truth at last is here for them to read. ... Now if they want to speak the truth, there'll be no one around to stop them. [Headline of Hirohito's speech "admitting" that the he is not a deity.] Now if they want to hear the truth, there'll 
be plenty of truth to hear. When they've read enough truth, when they've heard enough truth, when they've had enough first-hand experience with the truth, they'll be able to lead their own lives. ${ }^{24}$

\section{Re-Presenting the American Creed}

Next is the heart of the film, the depiction of the American Self and the Creed, requiring a new narrator with a smooth, paternalistic voice and a 1940s Hollywoodesque musical score - in sharp relief to the authoritarian narrator's presentation of the Japanese Other. Interestingly, as the production files reveal, this segment of the film was added rather late in the production schedule. According to the documents, the film was approved by 1 November 1945, but discussions about content - particularly regarding the depiction of the relationship between American troops and Japanese civilians, especially women, and of the relations among American soldiers, especially among white and black troops - continued for two months. ${ }^{25}$

The images which comprise this segment are of American GIs acting as information sources for women, reading comic books with Japanese children, trading laughs with Japanese policemen. These are stock images of the self-confident, easy-going American, readily able to laugh with and befriend the recent arch-enemy. The implicit message is that the Occupation forces are ready to embrace the child beaten for its own good. Comfort and guidance mixed with discipline is the undercurrent of the film. As long as the Japanese don't misbehave - because "we know what the score is" [scene of GIs on guard duty] - they can count on American beneficence.

24 Author's transcription, Our Job in Japan. The film's narrative and the textual script diverge slightly here.

25 Brig Gen John F. Davis, Chief, Information and Education Services, to Director, I \& E Division, 26 November 1945; and Lieutenant Walter Brecher, Morale Films Branch, to Captain Lehmann Katz, Army Pictorial Service, 27 December 1945; MPPF OF 15. 
Behind the ostensibly smooth facade of the film is ambivalence, demonstrated by accompanying documents in the production files, within both the Information \& Education Division of the War Department and the Army Signal Corps regarding the pedagogical aims of the film. The reaction to the initial screening in Washington was that the film was ambiguous in terms of "indicating to the soldier just what his job in Japan is." Military officials all agreed that the American soldier was "to set an example to [sic] the Japanese as to how a democracy actually works." The film was to teach the soldier that democracy meant "conducting himself in an orderly manner, minding his own business and not interfering with the business of others who are likewise behaving themselves." 26 The depiction of the relationship between American soldiers and the Japanese people was also a point of concern, as was that of the harmonious and pluralistic nature of American society as represented by the US military - a model of American democracy in action for the Japanese to follow.

In perhaps the most revealing of the production file memoranda, Walter Brecher of the Morale Films Branch of the Signal Corps notes the "need for extreme haste in connection with this film," and provides a 7-point list of images which were lacking in the film. Among these are shots of American troops "dancing and jitterbugging with Japanese girls;" on duty with Japanese troops; engaged in sport, either among themselves or "against Japanese with Japanese audiences looking on;" and at religious worship, "Catholic, Protestant, or Jewish, all three if possible." Judging by the language and the frequency with which the request is made, however, the most important but most difficult-to-obtain footage was "any type of recreational shots in which both white and negro troops take part together." 27 The original draft of the script, dated 13 September 1945, differs markedly from the final film version: the draft is

26 See Brig Gen John F. Davis to Director, 26 November 1945; MPPF OF 15.

27 Walter Brecher to Lehmann Katz, 27 December 1945; MPPF OF 15. 
devoid of any mention of American pluralism, and there is no supporting imagery of the American melting pot:

Getting rid of their war machine is one thing ... But it'll take a lot longer to get rid of their idea. This idea had been hammered into these people's heads. The United States Army can't hammer it out. They ... and only they can do that for themselves. They ... and only they ... can think their way out of this stuff. Our job is to see that they do it. Our job is to watch them while they do it. To watch them for tricks. And to slap down any who try to pull tricks. But the honest ones, the sincere ones, the ones who really want to make sense are being given every opportunity they need. We're kicking out the criminals who spiked their religion with propaganda. The big shots will ever again boss Japanese thinking through Shinto. ${ }^{28}$

The amended script contains eight lines inserted between the eighth and ninth paragraphs, words which were to be accompanied by images of "American soldiers mingling with civilians" and "conducting themselves with decorum:"

At the same time, these people, these honest ones, are looking to us to help them prove that our idea is better that the Japanese idea. These people are going to judge America and all Americans by us. That means we've got another job to do. That job is to be ourselves. By being ourselves, we can prove that what we like to call the American way ... or democracy ... or just plain old Golden rule common sense is a pretty good way to live. We can prove that most Americans don't believe in pushing people around, even when we happen to be on top. We can prove that most Americans do believe in a fair break for everybody, regardless of race or creed or color. We can show that most Americans believe that religion is a matter of a man's own conscience, and not something to be used for a political shakedown or to make trouble or to start wars. And by being ourselves, we can show them that though we're normally an easy-going people, people who like a good time as

28 Narration Script - Project \#11013, OUR JOB IN JAPAN, 13 September 1945; MPPF OF 15. 
well as the next man - maybe even a little more than the next man - just the same, we know what the score is. Because we do. ${ }^{29}$

The tenets of the American Creed are laid out clearly - fairness even in victory, equality of opportunity, and freedom of conscience and expression. Of these propositions, most problematic is the assertion that "most Americans believe in a fair break for everybody, regardless of race, or creed, or color," in light of the fact that the military and a significant portion of American society was indeed segregated by color in $1945 .{ }^{30}$ Matched with the text, "we can prove that most Americans do believe in a fair break for everybody," were to be images of "White and Colored US troops at work or play together." However, comparing the final edited film with the production notes, the producers were unable to find authentic footage of Black and white GIs "at work or play together" in the segregated pre-1948 United States Army. The images which appear with these words are of smiling soldiers in a mess hall. It appears that three white GIs and two Black soldiers are in the same queue for food; however, frame-by-frame inspection reveals that this image has been created by the editor from two separate film clips, one from an ostensibly white mess hall and the other from its Black "separate but equal" counterpart. ${ }^{31}$ The clips are spliced together presumably to give the effect of an integrated military, and by extension, a society which did not in fact exist. The editors attempt to bridge the "is-ought" gap, but ultimately their technical skills are not sufficient to mask the reality. The images themselves reflect the contradictions in American society circa

29 Signal Corps Photographic Center, Routing and Work Sheet, Walter Brecher to Casting Sec. Mr. Joyce, 10 January 1946; MPPF OF 15.

30 See Blum, VWas for Victory, esp. Ch 6, and Polenberg, One Nation Divisible, Ch 2.

31 Interestingly, the one place that such authentic footage exists is in the controversial 1946 film "Let There Be Light," a documentary about the treatment of combat-induced neurosis. Military psychiatric hospitals were apparently not segregated. One of the only circumstances in which black and white soldiers could come together as equals was as victims of war. I am indebted to Rebecca Plant for bringing this sad fact to my attention. 
1945. Even within an orientation film about the American mission in occupied Japan, the tensions within the Creed are inescapable.

At the risk of reading too much into this film, the closing section of the film might be seen as a metaphor for interracial relations in the United States, an eerie precursor of the use of the National Guard during the riots of the 1960s:

Let them think for themselves, talk for themselves, and educate themselves. Let them start to solve their own problems. [Images of the ruins of Tokyo.] This is what their old leaders brought them. Let them develop and follow new leaders ... We're sticking around until they've shown us ... convinced us ... that they've got themselves under control. We're sticking around because we take no more chances. [American troops marching]We're here to make it clear to the Japanese that their time has now come to make sense - modern, civilized sense. [Clip of the Liberty Bell ringing.] That is our job in Japan. ${ }^{32}$

\section{Making Sense of the American Creed}

Perhaps the most revealing thing about this film is what remains unsaid and unseen, namely the bombings of Hiroshima and Nagasaki and the internment of Japanese-Americans in concentration camps during the war. While the film is replete with images of dead children apparently the victims of the Japanese - who, the audience is told, waged "a war so disgusting, so revolting, so obscene, that it turned the stomach of the entire civilized world" - not a word or image of the post-nuclear scene. This is understandable, of course, in that the film, and the Occupation itself, intend to portray the American Way as the clear moral superior to the alternatives of both the Fascist past and the Communist present.

32 Author's transcription, Our Job in Japan. The film's narrative and the textual script diverge slightly here. 
Neither nuclear genocide nor ethnic concentration camps correspond with the image of moral preeminence, nor with the American Creed. Thus, the authoritarian narrator's assertion that "we have decided to make sure they make sense," leaves the thoughtful viewer to ponder whether "making sense" does not refer to a purification of the historical record to conform more closely to the American Creed. The military's cultural producers attempted to bridge vicariously in a filmically-imagined occupied Japan the "is-ought" gap which could not be bridged on the home front. However, the anxiety of official America, palpable in the behindthe-screen discussion, manifested itself in the film as well.

Thanks to Marcus Klee, Anna Berchidskaia and Rebecca Plant for excellent editorial and substantive suggestions. 